\title{
Distribution of chitinase in guinea pig tissues and increases in levels of this enzyme after systemic infection with Aspergillus fumigatus
}

\author{
Bernard Overdijk, ${ }^{1}$ Gé J. Van Steijn ${ }^{1}$ and Frank C. Odds ${ }^{2}$ \\ Author for correspondence: B. Overdijk. Tel: +3120 4448143. Fax: +31204448144. \\ e-mail: b.overdijk.medchem@med.vu.nl
}

\author{
1 Department of Medical \\ Chemistry, \\ Vrije Universiteit, \\ Van der Boechorststraat 7, \\ 1081 BT Amsterdam, \\ The Netherlands \\ 2 Janssen Research \\ Foundation, Department \\ of Bacteriology \\ and Mycology, \\ Turnhoutseweg 30, \\ B-2340 Beerse, Belgium
}

\begin{abstract}
Intravenous infection of guinea pigs with the fungus Aspergillus fumigatus resulted in increased levels of chitinase in serum and tissues of the animals. The molecular properties of the enzyme were demonstrated to be different from those of the fungal chitinase, but also from guinea pig lysozyme and $\beta-N$ acetylhexosaminidase. Bio-Gel P-100 gel filtration showed that in liver, spleen, heart and lung tissue of control animals there were two molecular mass forms present with apparent molecular masses of $35 \mathrm{kDa}$ and $15 \mathrm{kDa}$. In brain and serum, only the $35 \mathrm{kDa}$ form was detectable. Kidney showed only the $15 \mathrm{kDa}$ form. Upon infection the $35 \mathrm{kDa}$ form appeared in kidney and increased in the other tissues. When a less pathogenic form of the fungus was used the $35 \mathrm{kDa}$ form remained absent in kidney. In contrast to human serum chitinase, the enzyme from guinea pig serum and tissues did bind to concanavalin ASepharose. This was the case for both molecular mass forms. The mode of cleavage of the substrate 4-methylumbelliferyl-tri- $\mathrm{N}$-acetylchitotrioside (MU[GICNAC] ${ }_{3}$, where GICNAC is $\mathrm{N}$-acetylglucosamine) by the two forms of the enzyme was the same: both [GICNAC] ${ }_{2}$ and [GICNAC] ${ }_{3}$ were released. The chitinase activity levels in the control tissues showed a large variation in this order: spleen $>$ lung, kidney $>$ liver $>$ heart $>$ brain. The fact that spleen showed the highest chitinase level is in agreement with its major role as a lymphoid organ in cases of systemic infections. The relative increases upon infection were the highest for the tissues that showed low control values.
\end{abstract}

Keywords: chitinase, guinea pig tissues, A. fumigatus infection

\section{INTRODUCTION}

In 1994 we demonstrated for the first time that human serum contained chitinase activity, capable of hydrolysing the substrates chitin and ethylene glycolchitin and also the artificial substrates MU-[GlcNAc $]_{2-4}$ (Overdijk \& Van Steijn, 1994). We subsequently showed that the enzyme was also present in guinea pig serum and in rat liver (Overdijk et al., 1996a; Overdijk \& Van Steijn, 1994). Subcellular fractionation studies with rat liver homogenates showed that the enzyme has a lysosomal localization. The enzyme was not active against the lysozyme substrate Micrococcus lysodeikticus and thus appeared to be different from the human

Abbreviations: Con $\mathrm{A}$, concanavalin $\mathrm{A} ; \beta$-Hex, $\beta$-N-acetylhexosaminidase; MU, 4-methylumbelliferyl; MU-[GlcNAc] ${ }_{n}(n=1,2,3)$, the $\beta 1 \rightarrow 4$-linked mono/di/trisaccharides of $\mathrm{N}$-acetylglucosamine, linked to $\mathrm{MU}$. serum lysozyme. Moreover, the degradation of the substrate MU-[GlcNAc $]_{3}$ by human serum lysozyme was not affected by the chitinase inhibitor allosamidin.

In a recent paper we demonstrated that the chitinase activity in guinea pig blood increased after systemic infection with the fungus Aspergillus fumigatus (Overdijk et al., 1996a). That result confirmed our earlier speculation on the function of chitinase in mammals as a defence mechanism against invasion by a chitincontaining micro-organism. Flach et al. (1992) earlier proposed that various plant chitinases play a role in the hydrolysis of chitin-containing pathogens like fungi.

The aim of the work presented here was to find out in which guinea pig tissue chitinase activity could be found and to follow the effect of an experimental systemic infection with $A$. fumigatus on those activities. We also wanted to know which of the two molecular mass forms 
that have been described by Renkema et al. (1995) were present in the various tissues. Six different tissues (brain, kidney, liver, spleen, heart and lung) and serum were studied for chitinase activity. To discriminate between possible specific increases of the chitinase activity and a general stimulation of the lysosomal apparatus, we also determined the $\beta$ - $N$-acetylhexosaminidase $(\beta$-Hex) activity. The infection resulted in different effects for chitinase and $\beta$-Hex: chitinase activity increased more than that of $\beta$-Hex. Chitinase activity was higher in those tissues that play a major role in the immune system, particularly spleen. However, the relative increase of chitinase after infection was lower in these tissues. By contrast, brain and heart tissue, which contained lower control levels of chitinase activity, showed a sharper increase. Furthermore, the highermolecular-mass form of chitinase showed the highest relative increase upon infection.

\section{METHODS}

Fungus culture. For the study of chitinase activity in the fungus, A. fumigatus (B19119; originally isolated from a pigeon with aspergillosis) was inoculated at an initial concentration of approximately $10^{5}$ conidia $\mathrm{ml}^{-1}$ in $1000 \mathrm{ml}$ Sabouraud glucose broth (Oxoid) in a $2000 \mathrm{ml}$ Erlenmeyer flask. The flask was rotated at 120 r.p.m. and a temperature of $37^{\circ} \mathrm{C}$. After $7 \mathrm{~d}$ the culture was centrifuged at $1600 \mathrm{~g}$ for $10 \mathrm{~min}$. The supernatant fluid was discarded. The pellet was resuspended in approximately $20 \mathrm{ml}$ physiological saline and was homogenized with an Ultraturrax blender for $3 \mathrm{~min}$. The homogenate was stored at $-20^{\circ} \mathrm{C}$ until used for further study.

A. fumigatus infection of guinea pigs. Pathogen-free guinea pigs of approximately $500 \mathrm{~g}$ were infected by intravenous injection of $A$. fumigatus conidia (B19119) in physiological saline $(+0.05 \%$ SDS) via the lateral penis vein. The inoculum dose was estimated as 5000 c.f.u. per $\mathrm{g}$ body weight and the actual dose was determined by plate counting. As controls, a group of animals was sham-infected with saline $(+0.05 \%$ SDS). In some experiments, a less virulant isolate of $A$. fumigatus (J960180; received as an azole-resistant isolate from the lung of a neutropenic patient) with a dose of 4000 c.f.u. per $\mathrm{g}$ body weight was used. The $\mathrm{LD}_{50}$ for this isolate, determined on the basis of mean survival time, was approximately 100fold greater than that of B19119. Blood samples were collected from the retro-orbital plexus. Animals were killed at intervals after infection. Except in the pilot experiment, the brain, heart, kidney, liver, lung and spleen were smeared on plates of Sabouraud agar for detection of $A$. fumigatus. The organs were than deep-frozen and stored at $-20^{\circ} \mathrm{C}$.

Preparation of guinea pig tissue homogenates and 100000 $g$ supernatants. The stored tissues were thawed and homogenized in water containing $1 \%$ Triton X-100 (Merck) and $0.02 \%(\mathrm{w} / \mathrm{v}) \mathrm{NaN}_{3}$ with the aid of a Polytron blender. When the homogenates were used in column chromatography studies they were clarified by centrifugation at $100000 \mathrm{~g}$ for $30 \mathrm{~min}$.

Bio-Gel P-100 gel filtration chromatography. A Bio-Gel P-100 column (51 cm $\times 1 \mathrm{~cm}$ diameter; 100-200 mesh; Bio-Rad) was equilibrated in a buffer containing $0.02 \mathrm{M}$ sodium acetate, $0.1 \mathrm{M} \mathrm{NaCl}, 0 \cdot 1 \%(\mathrm{w} / \mathrm{v})$ Triton X-100 and $0.02 \%(\mathrm{w} / \mathrm{v})$ $\mathrm{NaN}_{3}$, adjusted to pH 5.5 with acetic acid (buffer A). The column was calibrated with the molecular mass markers human serum lysozyme $(14.4 \mathrm{kDa}$; gift of Dr J. Brouwers, Stichting Samenwerkende Delftse Ziekenhuizen, Delft, The Netherlands), equine myoglobin ( $17 \mathrm{kDa}$; Sigma) and chicken ovalbumin ( $44 \mathrm{kDa}$; Boehringer). Triton X-100 was removed from the $100000 \mathrm{~g}$ supernatants of guinea pig tissue homogenates with the aid of an Extracti-Gel D column (detergentremoving gel; Pierce). The enzyme preparation was then concentrated with a Centricon-10 microconcentrator (Amicon), and mixed with an equal volume of buffer $A$. This solution $(400 \mu \mathrm{l})$ was loaded on to the column. The flow rate was $2 \mathrm{ml} \mathrm{h}^{-1}$. Fractions of $0.45 \mathrm{ml}$ were collected and their enzyme activities and protein concentrations were determined as described below. In the case of guinea pig serum, undiluted sera were used $(400 \mu 1)$. The same column was also used for the chromatography of a chitinase preparation from the fungus itself. In that case $1 \mathrm{ml}$ of $A$. fumigatus homogenate was centrifuged at $100000 \mathrm{~g}$ for $30 \mathrm{~min}$. The resulting supernatant $(650 \mu \mathrm{l})$ was concentrated on a Centricon-10 microconcentrator to a volume of $30 \mu \mathrm{l}$ and diluted with buffer $\mathrm{A}$ to a volume of $500 \mu \mathrm{l}$ : a sample of $400 \mu \mathrm{l}$ was applied on to the column.

Affinity chromatography of guinea pig spleen chitinase on Con A-Sepharose. A spleen tissue homogenate $(1 \mathrm{ml})$ of an $A$. fumigatus-infected guinea pig (killed at day 4 after infection) was centrifuged at $100000 \mathrm{~g}$ for $30 \mathrm{~min}$. From the resulting supernatant $(800 \mu \mathrm{l})$ Triton $\mathrm{X}-100$ was removed with the aid of an Extracti-Gel D column in Con A buffer ( $0.05 \mathrm{M}$ sodium phosphate buffer $\mathrm{pH} 7 \cdot 4$, containing $0.15 \mathrm{M} \mathrm{NaCl}$ ). After concentration of the resulting preparation in a Centricon-10 microconcentrator the concentrate $(420 \mu \mathrm{l})$ was mixed with $580 \mu \mathrm{l}$ Con A buffer. This sample was applied on to the Con ASepharose column $\left(7 \mathrm{ml}\right.$ gel; $1.77 \mathrm{~cm}^{2}$; Pharmacia LKB Biotechnology), at a flow rate of $5 \mathrm{ml} \mathrm{h}^{-1}$. Fractions of $1 \mathrm{ml}$ were collected. After elution of unretained material with the Con A buffer, the column was eluted with 1.0 $\mathrm{M} \alpha$-methylmannoside(methyl- $\alpha$-D-mannopyranoside; Sigma) in Con A buffer containing $0.5 \mathrm{M} \mathrm{NaCl}$.

Enzyme and protein assays. Chitinase activities with the substrates 4-methylumbelliferyl- $\beta$-D- $N, N^{\prime}, N^{\prime \prime}$-triacetylchitotrioside and 4-methylumbelliferyl- $\beta$-D- $N, N^{\prime}$-diacetylchitobioside (MU-[GlcNAc] $]_{3,2}$; Sigma) were determined as follows. The substrates were dissolved in $1.0 \mathrm{M}$ sodium acetate buffer, $\mathrm{pH} 5 \cdot 5$, containing $0.02 \% \mathrm{NaN}_{3}$. The enzyme solution $(20 \mu \mathrm{l})$ was mixed with $30 \mu \mathrm{l}$ substrate solution, resulting in a final substrate concentration of $100 \mu \mathrm{M}$. In part of the experiments the chitinase inhibitor allosamidin from Streptomyces sp. 1713 ( $6 \mu \mathrm{M}$; gift of Drs A. Suzuki and A. Isogai, Department of Agricultural Chemistry, University of Tokyo) or ethylene glycol chitin ( $2 \mathrm{mg} \mathrm{ml}^{-1}$; Seikagaku) were mixed with the above enzyme-substrate solution. In the study to characterize the chitinase enzyme activity, $0.7 \mathrm{mU} \quad \beta$ - $N$-acetylhexosaminidase $(\beta$-Hex $)$ from jack bean (Sigma) was added to the above enzyme-substrate solution. For the substrate 4-methylumbelliferyl- $\beta$-D-N-acetylglucosaminide (MU-[GlcNAc] ; Sigma) a similar reaction mixture was used, but now with a Mcllvaine buffer of $\mathrm{pH} 4.4$ and a final substrate concentration of $600 \mu \mathrm{M}$. The reaction mixtures were incubated at $37^{\circ} \mathrm{C}$ for appropriate times and were stopped by addition of $1450 \mu \mathrm{l}$ of a $0.25 \mathrm{M}$ glycine/sodium carbonate buffer, $\mathrm{pH} 10.5$. The fluorescence of the liberated MU was measured as previously described (Overdijk et al., 1975). One unit of the above enzymes liberates $1 \mu \mathrm{mol} \mathrm{MU} \mathrm{min}^{-1}$. Lysozyme activity, with the substrate Micrococcus lysodeikticus (Sigma), was assayed according to Jollès (1962) at a temperature of $50^{\circ} \mathrm{C}$. Protein was determined by the Lowry method. When Triton X-100 
was present the BCA method (bicinchoninic acid protein assay kit; Sigma procedure no. TPRO-562; Sigma) was used.

Statistical data analysis. For the statistical data analysis we used Student's $t$-test and the Pearson correlation coefficient. In the experiment in which we studied four groups of guinea pigs (see Table 1), and where Student's $t$-test showed a significant difference between two groups, the ANOva procedure was used first to check whether there was a significant variation among the groups. Values of $P \leqslant 0.05$ were taken as statistically significant for all tests.

\section{RESULTS}

\section{Effect of intravenous infection with $A$. fumigatus on the chitinase activity in guinea pig tissues}

Table 1 presents the results of a pilot experiment in which we measured the enzyme activities of chitinase and $\beta$-Hex in the homogenates of six different tissues from four groups of three guinea pigs each. These animals were either infected with A. fumigatus B19119 $\left(4000\right.$ c.f.u. $\mathrm{g}^{-1}$ ) or were sham-infected with saline and were killed $30 \mathrm{~min}$ or $4 \mathrm{~d}$ after infection. Of the $A$. fumigatus-infected animals to be killed on day 4, one of the animals died on day 3 , so $n=2$ for this group. The specific chitinase activities, measured with the substrate $\mathrm{MU}-[\mathrm{GlcNAc}]_{3}$, were compared with those found for $\beta$ Hex, as measured with MU-[GlcNAc $]_{1}$. All chitinase activities presented in Table 1 were inhibitable ( $>95 \%$ ) with the specific chitinase inhibitor allosamidin (Koga $e t$ al., 1987) at $6 \mu \mathrm{M}$. The differences in enzyme levels between the tissues for chitinase were larger than those found for $\beta$-Hex. From the data in Table 1 we could calculate the factors by which the enzyme levels increased (IF) upon infection for the various tissues. For the chitinase activity in the tissues from the shaminfected animals we found no significant changes, with the exception of brain. In the A. fumigatus-infected animals there was a high increase for the brain tissue (IF
14-15), and much smaller but significant increases in kidney, liver and heart, with IF values of 2-3. Lung and spleen showed no significant increase upon $A$. fumigatus infection in this experiment. The $\beta$-Hex activity in the tissue homogenates showed no significant increases, irrespective of the type of infection. In a later experiment we substantiated the above results for a larger number of animals (see below).

\section{Bio-Gel P-100 gel filtration pattern of chitinase and $\beta$ - Hex in tissue homogenates of infected guinea pigs}

To find out whether the chitinase in the tissues of the guinea pig was comparable with the earlier described human and guinea pig serum enzyme (Overdijk et al., 1996a), we did the following experiment. The tissue homogenates from one of the three sham-infected animals that was killed on day 0 were centrifuged at $100000 \mathrm{~g}$ and the resulting supernatants were concentrated after removal of Triton X-100. The sample was then applied to a Bio-Gel P-100 gel filtration column (Fig. 1, left panels) to provide baseline data on chitinase elution profiles. The elution profiles for chitinase from the six examined tissue sources differed. Only that of brain was similar to the serum profile, showing a single peak of chitinase activity with an apparent molecular mass of approximately $35 \mathrm{kDa}$. Liver and spleen shared this $35 \mathrm{kDa}$ peak, but also contained a second peak with chitinase activity, eluting between the molecular mass markers myoglobin $(17 \mathrm{kDa})$ and lysozyme $(14.4 \mathrm{kDa})$, thus having an apparent molecular mass of approximately $15 \mathrm{kDa}$. Heart and lung tissue also showed two peaks, of which the $15 \mathrm{kDa}$ peak was relatively small (data not shown). Kidney contained only the $15 \mathrm{kDa}$ peak. All chitinase activity present in the peaks was inhibitable with allosamidin $(>90 \%)$. The $\beta$-Hex activity eluted together with the major protein peak in the void-volume of the column.

Table 1. Specific activities of chitinase and $\beta$-Hex in guinea pig tissue homogenates and serum

Four groups of guinea pigs $(n=3)$ were infected with saline or A. fumigatus ( 4000 c.f.u. $\mathrm{g}^{-1}$ ) and killed on the indicated days.

Enzyme activities in the tissue homogenates $(18 \%, \mathrm{w} / \mathrm{v})$, prepared in water containing $1 \%$ Triton X-100, and serum were determined in duplicate. Specific activities of chitinase $\left(\mathrm{mU} \mathrm{g} \mathrm{g}^{-1}\right)$ and $\beta$-Hex $\left(\mathrm{U} \mathrm{g}^{-1}\right)$ are given $( \pm \mathrm{SD})$.

\begin{tabular}{|c|c|c|c|c|c|c|c|c|}
\hline \multirow[t]{3}{*}{ Tissue } & \multicolumn{4}{|c|}{ Chitinase activity $\left(\mathrm{mU} \mathrm{g}^{-1}\right)$} & \multicolumn{4}{|c|}{$\boldsymbol{\beta}$-Hex activity $\left(\mathrm{U} \mathrm{g}^{-1}\right)$} \\
\hline & \multicolumn{2}{|c|}{ Sham-infection } & \multicolumn{2}{|c|}{ Infection } & \multicolumn{2}{|c|}{ Sham-infection } & \multicolumn{2}{|c|}{ Infection } \\
\hline & Day 0 & Day 4 & Day 0 & Day $4^{*}$ & Day 0 & Day 4 & Day 0 & Day $4 *$ \\
\hline Brain & $4 \cdot 9 \pm 1 \cdot 2$ & $9 \cdot 4 \pm 2 \cdot 5$ & $9 \cdot 4 \pm 2 \cdot 6$ & $136 \pm 30$ & $15 \cdot 8 \pm 3 \cdot 0$ & $14 \cdot 0 \pm 2 \cdot 5$ & $14 \cdot 9 \pm 1 \cdot 4$ & $18 \cdot 6 \pm 2 \cdot 7$ \\
\hline Kidney & $422 \pm 119$ & $639 \pm 135$ & $345 \pm 75$ & $802 \pm 135$ & $31.9 \pm 7 \cdot 8$ & $23 \cdot 0 \pm 6 \cdot 4$ & $22 \cdot 0 \pm 1 \cdot 9$ & $24 \cdot 5 \pm 3 \cdot 2$ \\
\hline Liver & $164 \pm 67$ & $250 \pm 64$ & $152 \pm 69$ & $403 \pm 57$ & $22 \cdot 6 \pm 2 \cdot 5$ & $19 \cdot 2 \pm 5 \cdot 3$ & $19 \cdot 9 \pm 1 \cdot 7$ & $22 \cdot 7 \pm 3 \cdot 7$ \\
\hline Spleen & $1957 \pm 733$ & $2054 \pm 580$ & $1196 \pm 440$ & $1624 \pm 902$ & $67 \cdot 2 \pm 18 \cdot 6$ & $49 \cdot 7 \pm 3 \cdot 8$ & $38 \cdot 1 \pm 7 \cdot 7$ & $34 \cdot 7 \pm 4 \cdot 4$ \\
\hline Heart & $25 \cdot 5 \pm 9 \cdot 8$ & $23 \cdot 0 \pm 5 \cdot 5$ & $20 \cdot 1 \pm 6 \cdot 7$ & $45 \cdot 8 \pm 5 \cdot 8$ & $7 \cdot 0 \pm 0 \cdot 7$ & $5 \cdot 2 \pm 1 \cdot 1$ & $5 \cdot 2 \pm 1 \cdot 3$ & $7 \cdot 4 \pm 0 \cdot 0$ \\
\hline Lung & $566 \pm 177$ & $583 \pm 180$ & $533 \pm 161$ & $751 \pm 92$ & $29 \cdot 6 \pm 8 \cdot 8$ & $23 \cdot 3 \pm 2 \cdot 4$ & $25 \cdot 7 \pm 10 \cdot 0$ & $29 \cdot 4 \pm 4 \cdot 7$ \\
\hline Serum & $21 \cdot 8 \pm 10 \cdot 8$ & $24 \cdot 0 \pm 2 \cdot 5$ & $15 \cdot 3 \pm 4 \cdot 3$ & $231 \pm 173$ & $6 \cdot 4 \pm 1 \cdot 9$ & $6 \cdot 2 \pm 1 \cdot 2$ & $6 \cdot 7 \pm 1 \cdot 7$ & $15 \cdot 9 \pm 8 \cdot 1$ \\
\hline
\end{tabular}

*Due to the death on day 3 of one of the animals, $n=2$. 

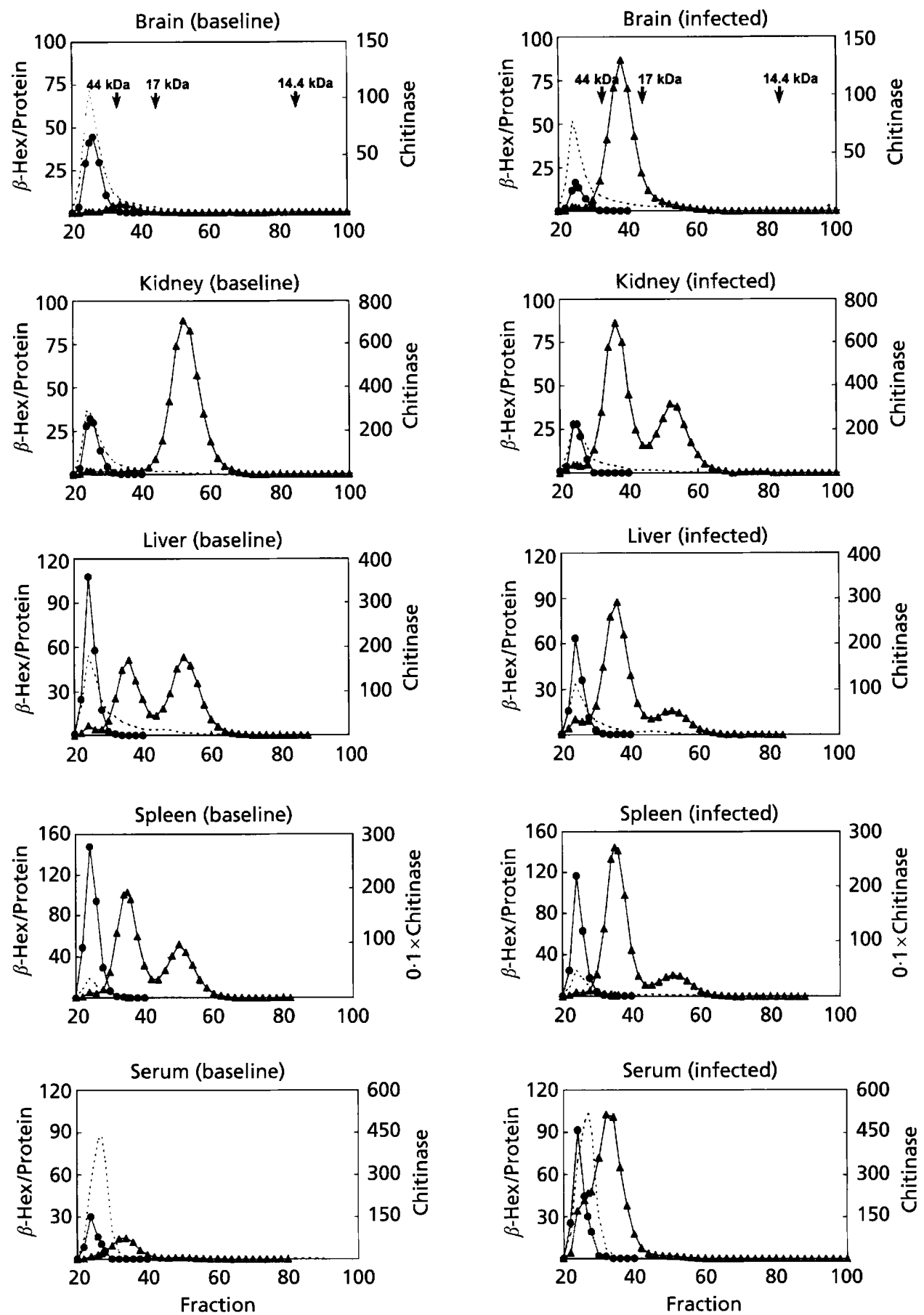

Fig. 1. Bio-Gel P-100 gel filtration pattern of chitinase from serum and from the $100000 \mathrm{~g}$ supernatants of homogenates of brain, kidney, liver and spleen of guinea pigs that were infected with $A$. fumigatus (strain B19119). The animals were killed $4 \mathrm{~d}$ after the infection. Sham-infected animals were killed after $30 \mathrm{~min}$ and were used to determine baseline data. For each tissue $400 \mu \mathrm{l}$ enzyme solution was applied, prepared and diluted as described in Methods. The serum sample $(400 \mu \mathrm{l})$ was not diluted. The arrows indicate the elution volumes of the following molecular mass markers: chicken ovalbumin $(44 \mathrm{kDa})$, equine myoglobin $(17 \mathrm{kDa})$ and human serum lysozyme $(14.4 \mathrm{kDa})$. Chitinase activities $\left(\Lambda ; \mu \mathrm{U} \mathrm{ml}^{-1}\right)$ were determined with the substrate $\mathrm{MU}$-[GIcNAc] $]_{3}$ and $\beta$-Hex activities $\left(0 ; \mathrm{mU} \mathrm{ml}^{-1} \text { ) with MU-[GlcNAc] }\right]_{1}$. The protein concentrations (dashed line), assayed with the BCA method, are given as $A_{566}(\times 1000)$. The following amounts of protein (mg) were applied to the columns shown in the baseline/infected panels: brain, 16.0/11.3; kidney, 9.0/7.5; liver, 11.2/6.6; spleen, 3.4/5.1; serum, 15.1/18.5. 

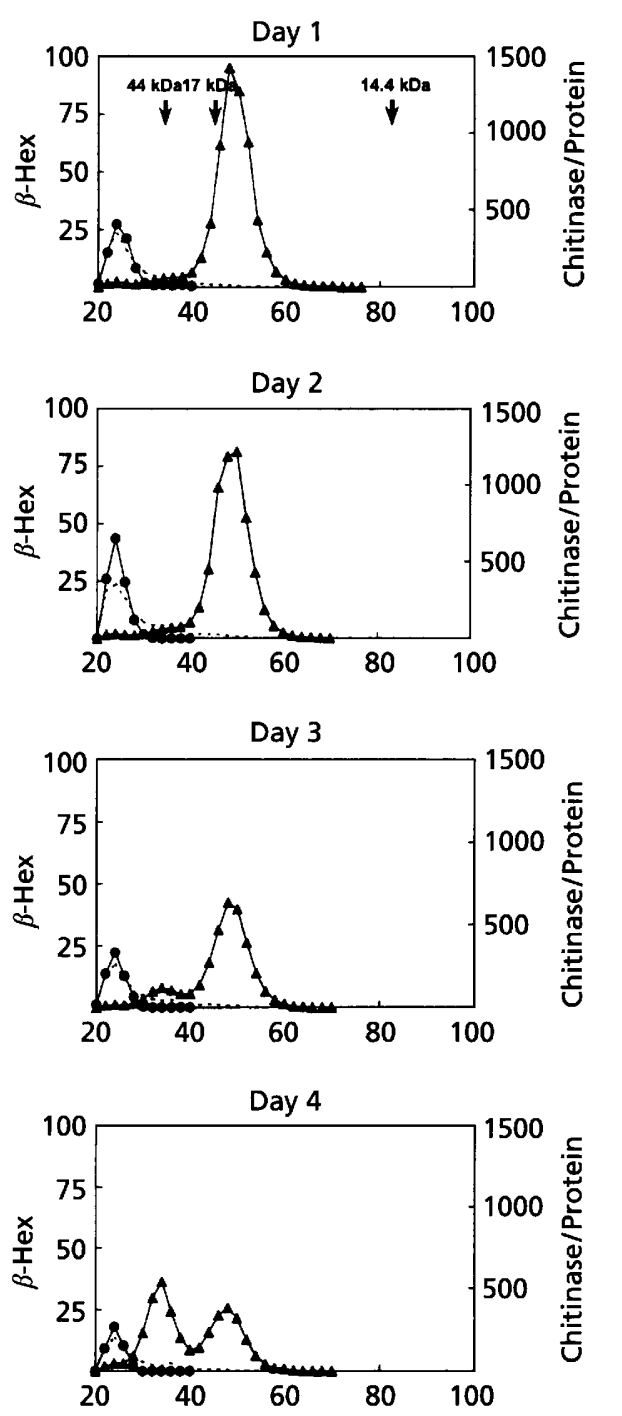

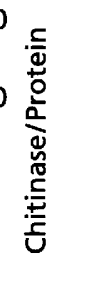

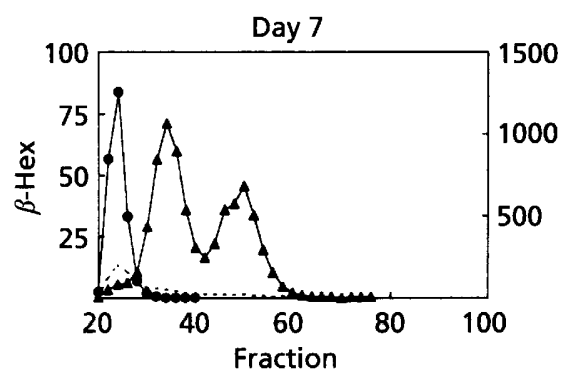

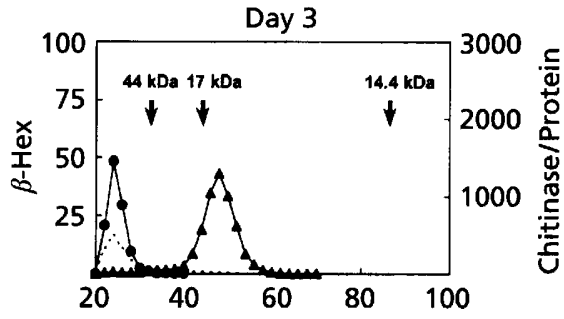
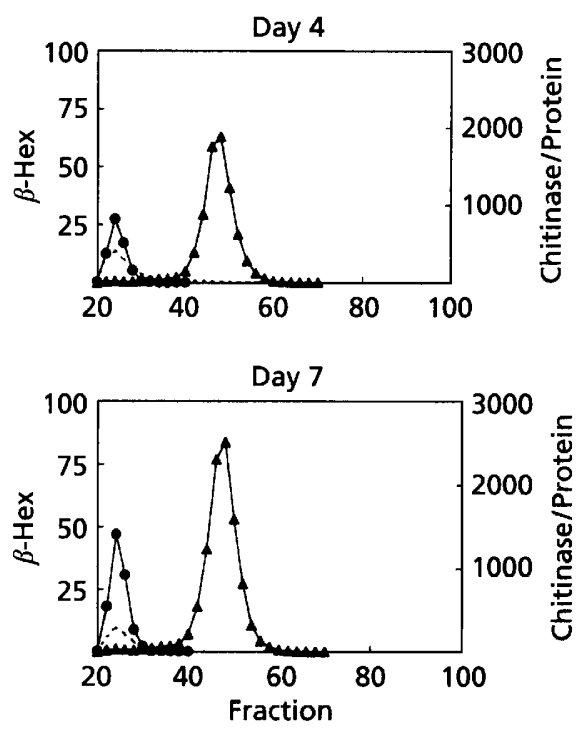

Fig. 2. Bio-Gel P-100 gel filtration pattern of chitinase from the $100000 \mathrm{~g}$ supernatants of kidney homogenates of guinea pigs that were killed at various days after infection with a virulent strain of $A$. fumigatus (strain B19119, left panels) or with the low-virulence strain $J 960180$ (right panels). The animals were killed at the indicated days after the infection. Chitinase activities $\left(\Delta ; \mu \mathrm{U} \mathrm{ml}^{-1}\right)$ were determined with the substrate MU-[GICNAC] ${ }_{3}$ and $\beta$-Hex activities $\left(0 ; \mathrm{mU} \mathrm{ml}^{-1}\right.$ ) with $\mathrm{MU}-[\mathrm{GlCNAC}]_{1}$. The protein concentrations (dashed line), assayed with the BCA method, are given as $A_{566}(\times 1000)$. The arrows indicate the elution volumes of molecular mass markers as in Fig. 1. The following amounts of protein $(\mathrm{mg})$ were applied to the columns shown in the virulent panels: day $1,7.6$; day $2,9.0$; day $3,5.8$; day $4,4.6$; day $7,5.2$. In the lowvirulence panels these amounts were: day $3,9.6$; day $4,9.0$; day $7, \mathbf{5} \cdot \mathbf{2}$.

As mentioned above we found two chitinase enzyme activity peaks in four of the six tissue homogenates of the sham-infected animals. To find out to which of these two peaks the increased chitinase activity was related, we performed similar gel filtration experiments with the homogenates of the various tissues from one of the $A$. fumigatus-infected animals that was killed on day 4 and which showed the highest chitinase levels in most of the tissues (Fig. 1, right panels). For brain we observed an increase of the peak at $35 \mathrm{kDa}$. No peak was seen at $15 \mathrm{kDa}$, in either control or infected animals. The kidney of a homogenate of a sham-infected animal showed only the $15 \mathrm{kDa}$ peak, but in the kidney of the animal infected with the fungus the $35 \mathrm{kDa}$ peak was also detected. The liver homogenate showed two peaks of comparable heights in the sham-infected animals. In the animal infected with A. fumigatus the $35 \mathrm{kDa}$ peak was clearly higher than the $15 \mathrm{kDa}$ peak. For a spleen homogenate a comparable result was obtained (Fig. 1, right panel), as was also the case for heart and lung (data not shown). The chitinase activity in all the peaks was inhibitable with allosamidin $(>95 \%)$. The shoulder in the chitinase 
elution profile for serum of the infected animals could be ascribed to $\beta$-Hex activity that led to the formation of $\mathrm{MU}-[\mathrm{GlcNAc}]_{1}$ from $\mathrm{MU}-[\mathrm{GlcNAc}]_{3}$.

To be sure that the changed elution profiles of the infected animal tissues were not caused by a placebo effect, we also made a Bio-Gel P-100 chromatogram of the kidney homogenate of one of the sham-infected animals that were killed on day 4 . The resulting elution profile for chitinase showed only a single peak at $15 \mathrm{kDa}$, like the profile on day 0 (data not shown).

To study the possible relationship between the duration of the infection and the observed increase of the $35 \mathrm{kDa}$ peak, we did the following experiment. A group of 10 guinea pigs was infected with A. fumigatus B19119 (4000 c.f.u. $\left.\mathrm{g}^{-1}\right)$. At days 1, 2, 3, 4 and 7 after infection, two animals were killed. All tissues from these animals were culture-positive for $A$. fumigatus. The $100000 \mathrm{~g}$ supernatants of the kidney homogenates were applied to a Bio-Gel P-100 gel filtration column and the fractions were assayed for chitinase and $\beta$-Hex activities and protein. The results for one of the two animals on each day are given in Fig. 2 (left panels). On days 1 and 2 only the $15 \mathrm{kDa}$ peak was present. On day 3 the $35 \mathrm{kDa}$ enzyme peak became detectable and increased in height 4 and $7 \mathrm{~d}$ after infection. The above results are for one animal of the two that were killed on the indicated days. The gel filtration patterns for the duplicates were qualitatively the same, although the activity levels varied to a relatively high extent, as can also be deduced from the high standard deviations presented in Table 4 (see below). Furthermore, the rate of appearance of the $35 \mathrm{kDa}$ peak varied for the different individual animals (results not shown).

When we repeated the above experiment with kidneys from a group of 10 animals that were infected with a less virulent isolate of A. fumigatus (strain J960180), we obtained the following results. No $35 \mathrm{kDa}$ peak was present, even after $7 \mathrm{~d}$ of infection, although we selected the homogenates with the highest gross chitinase activities on each of the three indicated days (Fig. 2, right panels). In this group of animals, positive cultures for $A$. fumigatus were obtained in all spleen tissues and in the majority of the other tissues.

\section{Calculation of the possible contribution of serum chitinase to the increased chitinase activity in the guinea pig brain tissue homogenate}

The chitinase in the guinea pig brain was approximately 15-fold higher after infection with A. fumigatus, an increase comparable with the increase found in guinea pig serum. For both brain and serum the increase factors were much higher than for the other tissues. The Bio-Gel P-100 chitinase activity profiles of the brain homogenates were also similar to the profiles found for the guinea pig sera. It was thus necessary to rule out the possibility that the increased activity in the brain homogenate was derived from circulating blood. For rat a blood volume of $40 \mu \mathrm{l}$ per $\mathrm{g}$ brain has been reported
Table 2. Estimation of the possible blood contribution to the induced chitinase activity in the brain of $A$. fumigatus-infected guinea pigs

The chitinase activities (assayed in duplicate) in brain homogenates and sera of four groups of guinea pigs are given. Group 1, sham-infected, day $0(n=3)$; group 2, sham-infected, day $4(n=3)$; group 3 , A. fumigatus infected, day $0(n=3)$; group $4, A$. fumigatus infected, day 4 (two individual values given). Data are based on brain homogenates $(20 \%, w / v$, in water).

\begin{tabular}{|c|c|c|c|}
\hline \multirow[t]{2}{*}{ Group } & \multicolumn{3}{|c|}{ Chitinase activity $\left(\mathrm{mU} \mathrm{m}^{-1}\right)$} \\
\hline & Homogenate & Serum & $\begin{array}{l}\text { Blood contribution } \\
\text { (\% of homogenate) }\end{array}$ \\
\hline 1 & $0 \cdot 10 \pm 0 \cdot 01$ & $0 \cdot 98 \pm 0 \cdot 48$ & $0 \cdot 005(8 \cdot 2)$ \\
\hline 2 & $0 \cdot 16 \pm 0 \cdot 04$ & $1 \cdot 42 \pm 0.23$ & $0 \cdot 007(7 \cdot 2)$ \\
\hline 3 & $0 \cdot 15 \pm 0 \cdot 04$ & $0 \cdot 69 \pm 0 \cdot 17$ & $0.004(3.7)$ \\
\hline \multirow[t]{2}{*}{4} & $2 \cdot 19$ & $25 \cdot 69$ & $0 \cdot 128(9 \cdot 4)$ \\
\hline & 1.76 & $6 \cdot 50$ & $0.033(2.9)$ \\
\hline
\end{tabular}

* Blood contribution calculations were based on the assumption that the blood volume of brain was $4 \%$.

(Yagen et al., 1991). With the aid of this value we calculated the data in Table 2 . The possible contribution of the serum chitinase activity to the brain values was calculated to be $3-10 \%$. These values are too low to explain the 15 -fold increase of chitinase activity in the guinea pig brain.

\section{Characterization of the two peaks of chitinase enzyme activity found in Bio-Gel P-100 gel filtration}

The action of chitinase on the substrate MU-[GlcNAc] $]_{3}$ can result either in the direct release of the trisaccharide from $\mathrm{MU}$, or in the release of the disaccharide chitobiose, resulting also in MU-[GlcNAc]. The latter substance can than be hydrolysed by $\beta$-Hex, resulting in the release of free GlcNAc and MU. To characterize the two gel filtration peaks with respect to these two different kinds of chitinase action we did the following experiment, with the results shown in Table 3 . Chitinase gel filtration peaks of the $100000 \mathrm{~g}$ supernatant of kidney homogenates from control and A. fumigatus-infected guinea pigs were incubated with or without jack bean $\beta$ Hex and with the substrates MU-[GlcNAc] $]_{3}$ or MU$[\mathrm{GlcNAc}]_{2}$. The direct release of $\mathrm{MU}$ from MU$[\mathrm{GlcNAc}]_{3}$ with the chitinase preparation was taken as $100 \%$ activity. Incubation with the chitinase enzyme from either peak together with the jack bean $\beta$-Hex resulted in a comparable increase in activity $(15-30 \%)$ for both gel-filtration-peak preparations from the infected animal. The same was true for the control animal, in which only the $15 \mathrm{kDa}$ peak is present, indicating that the intermediate product MU-[GlcNAc] $]_{1}$ was formed, together with the direct release of $[\mathrm{GlcNAc}]_{3}$. The results of similar experiments with the substrate MU- 
Table 3. Effect of jack bean $\beta$-Hex on the degradation of MU-[GICNAc $]_{2,3}$ by the enzyme activities present in the two $\beta$ Hex-free chitinase peaks from the Bio-Gel P-100 gel filtration

The second column (Chitinase) indicates the presence or absence of chitinase, taken from the $\beta$-Hex-free chitinase peaks (15 kDa and $35 \mathrm{kDa}$ ) from the Bio-Gel P-100 gel filtration of $100000 \mathrm{~g}$ supernatants from kidney homogenates of control (A) and infected (B) guinea pigs. The amounts of chitinase present in the incubation mixtures were: $7 \cdot 4 \mu \mathrm{U}(15 \mathrm{kDa} ;$ control); $3.2 \mu \mathrm{U}(15 \mathrm{kDa} ;$ infected $)$; $6.7 \mu \mathrm{U}(35 \mathrm{kDa}$; infected). In the third column the (additional) presence of $\beta$-Hex from jack bean $(0.7 \mathrm{mU})$ or absence is indicated ( $1 \mathrm{U}$ liberates $1 \mu \mathrm{mol} \mathrm{MU} \mathrm{min}{ }^{-1}$ from MU-[GlcNAc] $]_{1}$ at $\mathrm{pH} 5.5$ and $37^{\circ} \mathrm{C}$ ). The incubation mixtures were composed by mixing $30 \mu \mathrm{l}$ substrate, $10 \mu \mathrm{l}$ chitinase enzyme (or buffer) and $10 \mu \mathrm{l}$ jack bean enzyme (or buffer). The activities were determined in duplicate and are expressed as percentage of the activities observed in the absence of the jack bean enzyme. The homogenates from which the gel filtration peaks originate showed specific chitinase activities with the substrate $\mathrm{MU}-[\mathrm{GlcNAc}]_{3}$ of $546 \mathrm{mU} \mathrm{g}^{-1}(\mathrm{~A})$ and $707 \mathrm{mU} \mathrm{g}^{-1}(\mathrm{~B})$, respectively.

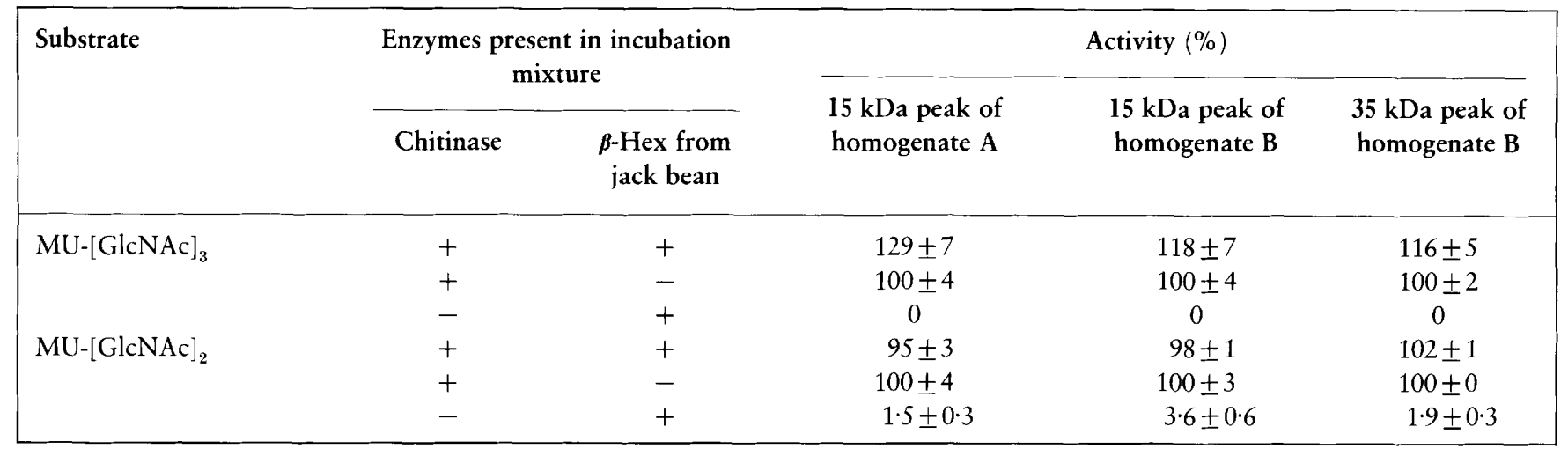

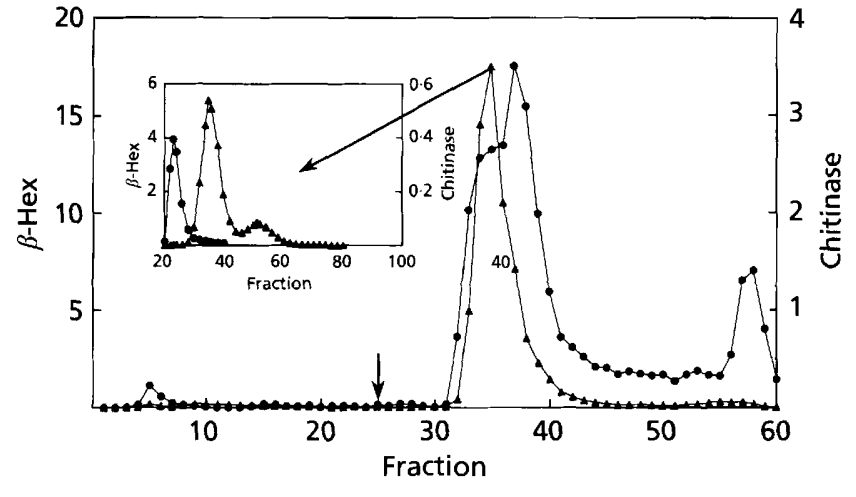

Fig. 3. Con A-Sepharose chromatography of the $100000 \mathrm{~g}$ supernatants of a spleen homogenate from a guinea pig that was infected with $A$. fumigatus (strain B19119) and Bio-Gel P$100 \mathrm{gel}$ filtration of the chitinase peak fraction. The animal was killed on day 4 after the infection The arrow at fraction 25 of the Con A-Sepharose chromatogram indicates the start of the elution with $\alpha$-methylmannoside. The inset shows the Bio-Gel P$100 \mathrm{gel}$ filtration profile of the peak fraction (no. 35) of the chitinase activity peak that eluted with $\alpha$-methylmannoside. Chitinase activities $\left(\boldsymbol{\Delta} ; \mathrm{mU} \mathrm{ml}^{-1}\right)$ were determined with the substrate $\mathrm{MU}$-[GlcNAc $]_{3}$ and $\beta$-Hex activities $\left(0 ; \mathrm{mU} \mathrm{ml}^{-1}\right)$ with MU-[GlcNAc] $]_{1}$. The amount of protein applied to the Con ASepharose column was $6.0 \mathrm{mg}$.

$[\mathrm{GlcNAc}]_{2}$ showed that no additional $\beta$-Hex activity was found with this substrate, indicating that this substrate was directly hydrolysed to $[\mathrm{GlcNAc}]_{2}$ and free MU.

The above-mentioned chitinase gel filtration peaks of kidney from control and A. fumigatus-infected guinea pigs were also incubated with $\mathrm{MU}-[\mathrm{GlcNAc}]_{3}$, together with the substrate ethylene glycol $\left(2 \mathrm{mg} \mathrm{ml}^{-1}\right)$, acting as an inhibitor for the release of MU from MU-[GlcNAc $]_{3}$. For all the three enzyme samples $98 \%$ inhibition was found.

Human serum chitinase does not bind to Con ASepharose (Den Tandt et al., 1988). To find out whether the same was true for the two gel filtration peaks from guinea pig tissues, we performed the following experiment. A $100000 \mathrm{~g}$ supernatant of a spleen homogenate $(1 \mathrm{ml})$ of an A. fumigatus-infected guinea pig (killed after $4 \mathrm{~d}$ infection) was applied to a Con ASepharose column. Only in the fractions that eluted in the presence of $\alpha$-methylmannoside was chitinase activity present, with a recovery of $74 \%$ (Fig. 3). When the chitinase fraction with the highest activity from the Con A-Sepharose column (fraction 35) was concentrated, mixed with buffer A, and applied to the Bio-Gel P-100 gel filtration column, the gel filtration profile (inset of Fig. 3) looked exactly the same as the profile of the original spleen tissue homogenate; two peaks of chitinase activity were present.

When we applied a guinea pig serum sample to the Con A-Sepharose column, the chitinase enzyme also bound (data not shown).

\section{Discrimination between guinea pig tissue chitinase activity and chitinase of $\boldsymbol{A}$. fumigatus by Bio-Gel P- 100 gel filtration}

To rule out the possibility that the increases in chitinase activities found for the guinea pig serum and for many of the tissues was of A. fumigatus origin, we prepared a 


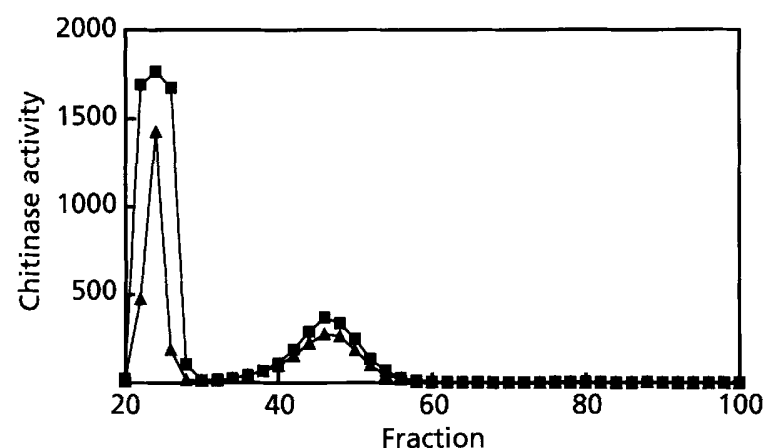

Fig. 4. Bio-Gel P-100 gel filtration pattern of chitinase from the $100000 \mathrm{~g}$ supernatants of the homogenate of a suspension of A. fumigatus (strain B19119). The $100000 \mathrm{~g}$ supernatant was prepared from the homogenate as described in Methods. Chitinase activities were determined with the substrates MU[GlCNAC] $_{2}(\boldsymbol{\square})$ and MU-[GICNAc] $]_{3}(\boldsymbol{\Delta})$. The activities are given in arbitrary fluorescence values. The time of incubation was $20 \mathrm{~h}$. The blunt form of the peak of the enzyme activity with the substrate $\mathrm{MU}$-[GIcNAc] $]_{2}$ around fraction number 24 indicates that the substrate must have been completely consumed at an incubation time less than $20 \mathrm{~h}$.

$100000 \mathrm{~g}$ supernatant of a homogenate of the fungus. A sample of this supernatant was then applied to a Bio-Gel P-100 gel filtration column. As was previously described (Overdijk et al., 1996a, b) for a Superose $12 \mathrm{HR}$ column, chromatography of the A. fumigatus supernatant and determination of the chitinase activity in the fractions with the MU-[GlcNAc $]_{2,3}$ substrates resulted in two enzyme activity peaks. The first peak that eluted from the column represented a (non-reducing end) chitobiase or a $\beta$-glucosaminidase and the second peak appeared to be a chitinase. A similar result was obtained in the present work where we used a Bio-Gel P-100 gel filtration column (Fig. 4). The peak that eluted at fraction 24 represents a (non-reducing end) chitobiase or a $\beta$-glucosaminidase, causing the difference between the peak height for the two substrates MU-[GlcNAc] $]_{2}$ and $\mathrm{MU}-[\mathrm{GlcNAc}]_{3}$. The fungus chitinase enzyme activity eluted with a peak at fraction 46, more or less corresponding with the guinea pig tissue gel filtration peak of $15 \mathrm{kDa}$. The heights of the peaks for the two substrates MU-[GlcNAc] $]_{2}$ and MU-[GlcNAc] $]_{3}$ differed much less than that of the peak at fraction 24 . Increases of chitinase activities from guinea pig origin after infection with the fungus are reflected in increases of the chitinase peak of the tissue enzyme at $35 \mathrm{kDa}$, which has an elution volume that is clearly different from the chitinase peak of the fungus $(15 \mathrm{kDa})$.

\section{Chitinase activity levels and their increase after $A$. fumigatus infection}

To confirm the conclusions that can be drawn from the data presented in Table 1, we performed the following experiment. Two groups of 10 guinea pigs each were infected with $A$. fumigatus B19119 (6000 c.f.u. $\left.\mathrm{g}^{-1}\right)$. The first group was killed on day 0 (30 min after infection), the second group was killed on day 4. A. fumigatus was recovered post mortem from all tissues of both groups of animals, with the exception of the brain tissue of one animal that was killed on day 4 . The chitinase and $\beta$-Hex activities and the protein concentration in the tissue homogenates $(20 \%, \mathrm{w} / \mathrm{v}$, in water, containing $1 \%, \mathrm{w} / \mathrm{v}$, Triton X-100) and in the sera were determined and the data were analysed as presented in Table 4 . In agreement with the results of the pilot experiment presented in Table 1, the differences in enzyme levels between the control tissues for chitinase were much higher than those found for $\beta$-Hex. For chitinase, spleen had the highest activity, followed by lung and kidney (with comparable enzyme levels), liver, heart and brain in this order. $\beta$-Hex showed the same order of activity levels with the exception of the latter two tissues.

For the $10 \mathrm{~A}$. fumigatus-infected animals that were killed on day 4 the following observations were made.

Table 4. Specific activities ( \pm SD), increase factors (IF) and their significance $(P)$ of chitinase and $\beta$-Hex in tissue homogenates and sera from $A$. fumigatus-infected guinea pigs

Two groups of guinea pigs $(n=10)$ were infected with A. fumigatus B19119 (6000 c.f.u. $\left.\mathrm{g}^{-1}\right)$ and killed on the indicated days. Enzyme activities were determined in the tissue homogenates $(20 \%, \mathrm{w} / \mathrm{v}$, in $1 \%$ Triton X-100) and sera. For the homogenates of spleen, kidney, lung and liver, the activities were determined in quadruplicate; for serum, brain and heart, duplicate determinations were done. All tissues were positive for A. fumigatus by culture of tissue homogenate.

\begin{tabular}{|c|c|c|c|c|c|c|c|c|}
\hline \multirow[t]{2}{*}{ Tissue } & \multicolumn{4}{|c|}{ Chitinase activity $\left(\mathrm{mU} \mathrm{g}^{-1}\right)$} & \multicolumn{4}{|c|}{$\beta$-Hex activity $\left(\mathbf{U ~ g}^{-1}\right)$} \\
\hline & $\begin{array}{c}\text { Infection day } \\
0\end{array}$ & $\begin{array}{c}\text { Infection day } \\
4\end{array}$ & IF day $0 \rightarrow 4$ & $\boldsymbol{P}$ & $\begin{array}{c}\text { Infection day } \\
0\end{array}$ & $\begin{array}{c}\text { Infection day } \\
4\end{array}$ & IF day $0 \rightarrow 4$ & $P$ \\
\hline Brain & $3 \cdot 5 \pm 1 \cdot 4$ & $58 \cdot 1 \pm 58 \cdot 4$ & $16 \cdot 5$ & 0.0085 & $11 \cdot 8 \pm 0 \cdot 9$ & $11 \cdot 0 \pm 0 \cdot 6$ & 0.9 & 0.0337 \\
\hline Kidney & $322 \pm 69$ & $638 \pm 188$ & $2 \cdot 0$ & $<0.0001$ & $24 \cdot 3 \pm 4 \cdot 1$ & $19 \cdot 8 \pm 2 \cdot 4$ & 0.8 & 0.0085 \\
\hline Liver & $112 \pm 28$ & $191 \pm 63$ & $1 \cdot 7$ & 0.0019 & $14 \cdot 3 \pm 3 \cdot 2$ & $19 \cdot 2 \pm 3 \cdot 3$ & $1 \cdot 3$ & $0 \cdot 0031$ \\
\hline Spleen & $1223 \pm 371$ & $1483 \pm 696$ & $1 \cdot 2$ & $0 \cdot 3111$ & $36 \cdot 4 \pm 5 \cdot 6$ & $27 \cdot 8 \pm 3 \cdot 3$ & $0 \cdot 8$ & 0.0005 \\
\hline Heart & $9 \cdot 8 \pm 2 \cdot 8$ & $40 \cdot 1 \pm 14 \cdot 3$ & $4 \cdot 1$ & $<0.0001$ & $6 \cdot 3 \pm 0 \cdot 7$ & $6.4 \pm 0.6$ & $1 \cdot 0$ & 0.6985 \\
\hline Lung & $390 \pm 99$ & $490 \pm 215$ & $1 \cdot 3$ & $0 \cdot 1943$ & $23 \cdot 9 \pm 3 \cdot 5$ & $17 \cdot 3 \pm 5 \cdot 2$ & $0 \cdot 7$ & 0.0033 \\
\hline Serum & $21 \cdot 9 \pm 3 \cdot 5$ & $105 \pm 55$ & $4 \cdot 8$ & $0 \cdot 0002$ & $4 \cdot 1 \pm 0 \cdot 5$ & $7 \cdot 9 \pm 2 \cdot 3$ & 1.9 & 0.0001 \\
\hline
\end{tabular}


The chitinase enzyme activities in Table 4 show significant increases for serum (IF 4.8), brain (IF 16.5), kidney (IF 2.0), liver (IF 1.7) and heart (IF 4.1). For spleen and lung no significant differences from the control group were found. For $\beta$-Hex, IFs of 1.9 for serum and 1.3 for liver were observed. Small but significant decreases were found for brain, kidney, spleen and lung (IF 0.7-0.9). For heart no significant difference was found between the two groups of animals.

As already mentioned, the possible contribution of the blood activity $(3-10 \%)$ was too small to explain the relatively high increase of chitinase activity in the guinea pig brain after infection. To confirm this conclusion for all the tissues that we examined, we calculated the Pearson correlation coefficients for the chitinase activities in both groups of animals (data not shown). For both groups that were killed on day 0 and day 4 there appeared to be no correlation between the serum chitinase activities and the tissue levels. When we calculated the correlation coefficients between the various tissues no correlation could be found for any pair of tissues (e.g. brain versus the other tissues; heart versus the other tissues, etc.). These calculations thus showed that the animal with the highest chitinase level in a particular tissue did not necessarily have the highest level in its other tissues when compared with other animals in the group.

\section{DISCUSSION}

The results of the pilot experiment presented in Table 1, and the experiment with a larger group of animals summarized in Table 4 confirmed our previous findings on the effect of systemic infections with A. fumigatus on chitinase and $\beta$-Hex levels in the serum of guinea pigs (Overdijk et al., 1996a, b). In serum the chitinase activity increased much more than that of $\beta$-Hex. Of the six tissues studied here (kidney, liver, spleen, lung, heart, brain) the relative increases of chitinase activity resulting from the infection were much lower than in serum, with the exception of brain and heart. In brain tissue we saw a relatively low specific activity for chitinase on day 0 but this activity increased by a much higher factor. Heart tissue showed an increase factor that was comparable with that of serum. With the exception of one brain homogenate, all the tissue samples from infected animals were positive for A. fumigatus by culture. Tissue burdens were not quantified in these experiments.

The fact that the measured chitinase activities were all inhibitable with allosamidin was one proof that the observed hydrolytic activity towards the MU-[GlcNAc $]_{3}$ substrate was of the chitinase rather than the $\beta$-Hex type. A second proof for the chitinase character of the enzyme was the observation that in the presence of ethylene glycol chitin, the MU-[GlcNAc] $]_{3}$-hydrolytic activity was almost completely inhibited. The possibility that lysozyme might have hydrolysed the substrate was excluded, since that enzyme is not inhibited by allosamidin (Overdijk \& Van Steijn, 1994). Further support that the hydrolysis was due to chitinase activity came from the following facts. Bio-Gel P-100 gel filtration profiles of the various $\mathrm{MU}-[\mathrm{GlcNAc}]_{3^{-}}$ hydrolysing enzymes showed that lysozyme and $\beta$-Hex eluted from the column at volumes clearly different from that of chitinase. Furthermore, the increased chitinase activity in the infected animals was not paralleled by increased levels of $\beta$-Hex, which should be the case if $\beta$ Hex were responsible for the observed release of $M U$ from MU-[GlcNAc $]_{3}$.

The reported molecular masses of the chitinases differ, depending on the method of estimation. In gel filtration studies of the native enzyme, the reported apparent molecular masses are lower than in SDS-PAGE studies. Renkema et al. (1995) used the name chitotriosidase for the human chitinase. They found for the enzyme from spleen tissue of a patient with Gaucher's disease two forms with pI values of $7 \cdot 2$ and $8 \cdot 0$. The pI $7 \cdot 2$ form had an apparent molecular mass of $37 \mathrm{kDa}$ on Sephadex G100 , and $50 \mathrm{kDa}$ on SDS-PAGE. For the pI 8.0 form these authors reported values of $29 \mathrm{kDa}$ (Sephadex) or $39 \mathrm{kDa}$ (SDS-PAGE). In earlier work with human serum chitinase we found that the enzyme showed affinity for the agarose-based gel filtration media Superose $12 \mathrm{HR}$ and Sepharose CL-6B (Overdijk et al., 1994) and also for Sephacryl S-300 HR, which is a polymer of allyldextran and $N, N^{\prime}$-methylenebisacrylamide (unpublished result). This affinity results in underestimates of the molecular masses of chitinase. On Bio-Gel P-100 or P-150, human serum chitinase and also the guinea pig serum enzyme eluted at a much higher apparent molecular mass of $35 \mathrm{kDa}$. In the various tissues of the guinea pig either one or two molecular mass forms were found $(15 \mathrm{kDa}$, $35 \mathrm{kDa})$. Brain tissue and serum from the sham-infected animals contained only the $35 \mathrm{kDa}$ form, whereas kidney showed only the $15 \mathrm{kDa}$ form. Upon infection with the A. fumigatus (strain B19119), the $35 \mathrm{kDa}$ form appeared (when it was absent before) or increased in peak height (when it was already present before). The results in Fig. 2 (left panels) show a tendency for the $35 \mathrm{kDa}$ peak to increase with time. Whether this protein is a precursor for the $15 \mathrm{kDa}$ enzyme (perhaps by proteolytic cleavage) is unknown. However, Renkema et al. (1997) found in macrophages that the highmolecular-mass form of the enzyme was a precursor for the low-molecular-mass form. It was notable that the attenuated strain of A. fumigatus (J960180) apparently did not lead to the appearance of the $35 \mathrm{kDa}$ form of chitinase, even though we selected for chromatography the samples with the highest overall enzyme levels at the various time points. Even after $7 \mathrm{~d}$ infection only the $15 \mathrm{kDa}$ form was present in kidney, in contrast to the situation with strain B19119.

The surprising observation that brain showed the highest increase factor upon infection, together with the fact that it had the lowest specific chitinase activity at day 0 , raised the question whether this increase could be ascribed to the tissue blood content of the homogenate. This explanation could be excluded on the basis of calculation of the maximal amount of enzyme activity present in the homogenates, ascribable to blood. Since 
no data on the blood volume in guinea pig brains could be found in the literature, the blood volume of rat brain was taken. Even if the highest volume that could be found in the literature was taken $\left(40 \mu \mathrm{g} \mathrm{g}^{-1}\right.$; Yagen et al., 1991), the increase in the serum level of chitinase could not explain the large increase for the brain tissue. The same conclusion could be drawn for the other tissues studied. This conclusion was based on the fact that there was no correlation between the increase of serum chitinase and the increases in the enzyme level in the tissues of a particular animal. Increased chitinase levels in blood could thus not be the exclusive cause of increased tissue levels.

We reported earlier that human serum chitinase did not bind to Con A-Sepharose (Den Tandt et al., 1988; Overdijk et al., 1994). This finding was confirmed by Renkema et al. (1995). It was therefore surprising that the enzyme from guinea pig blood did bind to this lectin. This would suggest that the guinea pig chitinase is glycosylated. For spleen, one of the tissues that contained both the $15 \mathrm{kDa}$ and $35 \mathrm{kDa}$ forms, we showed that the Bio-Gel P-100 gel filtration pattern of the Con A-binding chitinase activity was identical with the pattern of a spleen supernatant that was applied to the Bio-Gel column directly. It could therefore be concluded that both molecular mass forms bind to Con ASepharose. A control experiment with a human serum sample on the same Con A-Sepharose column confirmed the non-binding character of the human enzyme, as we reported earlier.

The results in Table 3 show that both molecular mass forms show identical degradation pathways towards the two artificial MU-substrates used in this study. With $\mathrm{MU}-[\mathrm{GlcNAc}]_{2}$ the disaccharide was cleaved from the MU-group in one step. The latter conclusion was based on the fact that the concomitant presence of a high amount of jack bean $\beta$-Hex did not result in an additional amount of MU. With the trisaccharide substrate, two different routes of cleavage were found, resulting in $[\mathrm{GlcNAc}]_{3}$ and $[\mathrm{GlcNAc}]_{2}$, respectively. The formation of the disaccharide was shown by the fact that the presence of jack bean $\beta$-Hex resulted in the additional release of $\mathrm{MU}$ from its substrate MU$[\mathrm{GlcNAc}]_{1}$. The latter substance can have been formed only by the action of chitinase, since the control experiment in which tissue chitinase was absent showed that no measurable amount of MU was detectable. The chitinase character of the enzyme activity in both molecular mass fractions was further demonstrated by the experiment in which ethylene glycol chitin was present together with the substrate $\mathrm{MU}-[\mathrm{GlcNAc}]_{3}$, resulting in a reduction of the $\mathrm{MU}-[\mathrm{GlcNAc}]_{3}$ hydrolysis with more than $98 \%$.

Although we demonstrated earlier that the increasing activities of chitinase in guinea pig serum upon infection with A. fumigatus was not of fungal origin (Overdijk et al., 1996a, b), we had to demonstrate that this was also the case in the present study for the tissue enzymes. The major increasing fractions from the infected guinea pig tissue homogenates eluted from a Bio-Gel P-100 column at $35 \mathrm{kDa}$. The fungal chitinase activity eluted at a position $(15 \mathrm{kDa})$ that was clearly different. Moreover, the high-molecular-mass peak around fraction 24 with enzyme activity towards MU-[GlcNAc $]_{2,3}$ (see Fig. 4) was absent in similar chromatograms of the tissues.

The initial chitinase activities in sham-infected animals or in A. fumigatus-infected animals at day 0 differed considerably in the various tissues. In both the pilot experiment (Table 1 ) and the experiment with the larger group of animals (Table 4) the specific activity in brain, the organ with the lowest value, was a factor of $100-400$ lower than that in spleen, the tissue with the highest level. These differences were much smaller (factors of only $3-4)$ for the specific activities of $\beta$-Hex. The tissues with the high initial chitinase activities, e.g. spleen and lung, showed no or non-significant increases upon infection, whereas the tissues with the lower initial levels, such as brain, heart and also serum, showed much higher increase factors.

When we first reported the presence of chitinase in human serum, we speculated that it might have a role in the defence against chitinous pathogens, such as fungi (Overdijk et al., 1994). This hypothesis was substantiated by our finding that, in guinea pig serum, chitinase levels increased in a time-dependent manner after a systemic infection with $A$. fumigatus and that this increase could be prevented by antifungal treatment (Overdijk et al., 1996a). In the latter paper we showed that only those antifungal agents that are effective against $A$. fumigatus diminished the increase. Davies \& Pope (1978) showed that systemic infection of Balb/c mice with $A$. fumigatus, followed by treatment with crude chitinase preparations in combination with normally ineffective antifungal agents, resulted in an increase of the survival time of the mice. In the present study we found that in spleen, a secondary lymphoid organ that is of major importance in the eradication of circulating pathogens, the chitinase level before infection is extremely high compared with that of other tissues such as heart and brain. However, the response to infection in the latter tissues was relatively the highest of the six tissues studied. The high chitinase level in lung tissues can be explained by the role of this organ in the defence against air-borne pathogens.

In summary, we have demonstrated that systemic infection of guinea pigs with $A$. fumigatus leads to increased tissue levels of chitinase. These increases are relatively higher for the tissues that show low baseline values for chitinase activity. The apparent molecular mass of the increased chitinase is $35 \mathrm{kDa}$. The relative amount of the $35 \mathrm{kDa}$ form in a tissue homogenate increases in a time-dependent manner and is lower or absent when the animals are infected by less virulent strains of the fungus, as was demonstrated for kidney.

\section{ACKNOWLEDGEMENTS}

Drs A. Suzuki and A. Isogai (Department of Agricultural Chemistry, University of Tokyo, Japan) are thanked for their gift of allosamidin and Dr J. Brouwer (Stichting Samen- 
werkende Delftse Ziekenhuizen, Delft, The Netherlands) for his gift of human serum lysozyme. We are grateful to F. van Gerven for technical help with the animal infections.

\section{REFERENCES}

Davies, D. A. L. \& Pope, A. M. S. (1978). Mycolase, a new kind of systemic antimycotic. Nature 273, 235-236.

Den Tandt, W. R., Inaba, T., Verhamme, I., Overdijk, B., Brouwer, J. \& Prieur, D. (1988). Non-identity of human plasma lysozyme and 4-methylumbelliferyl-tetra- $N$-acetyl- $\beta$-D-chitotetraoside hydrolase. Int J Biochem 20, 713-719.

Flach, J., Pilet, P.-E. \& Jollès, P. (1992). What's new in chitinase research? Experientia 48, 701-716.

Jolles, P. (1962). Lysozyme from rabbit spleen and dog spleen. Methods Enzymol 5, 137-140.

Koga, D., Isogai, A., Sakuda, S., Matsumoto, S., Suzuki, A., Kimura, A. \& Ide, A. (1987). Specific inhibition of Bombyx mori chitinase by allosamidin. Agric Biol Chem 51, 471-476.

Overdijk, B. \& Van Steijn, G. J. (1994). Human serum contains a chitinase: identification of an enzyme, formerly described as 4-methylumbelliferyl-tetra- $N$-acetylchitotetraoside hydrolase (MU-TACT hydrolase). Glycobiology 4, 797-803.

Overdijk, B., Van der Kroef, W. M. J., Veltkamp, W. A. \& Hooghwinkel, G. J. M. (1975). The separation of bovine brain $\beta$ $N$-acetyl-D-glucosaminidase C. Biochem J 151, 257-261.
Overdijk, B., Van Steijn, G. J. \& Den Tandt, W. R. (1994). Partial purification and further characaterization of the novel endoglucosaminidase from human serum that hydrolyses 4-methylumbelliferyl- $N$-acetyl- $\beta$-D-chitotetraoside (MU-TACT hydrolase). Int J Biochem 26, 1369-1375.

Overdijk, B., Van Steijn, G. J. \& Odds, F. C. (1996a). Chitinase levels in guinea pig blood are increased after systemic infection with Aspergillus fumigatus. Glycobiology 6, 627-634.

Overdijk, B., Van Steijn, G. J. \& Odds, F. C. (1996b). Chitinase levels in guinea pig blood are increased in experimentally induced aspergillosis. In Chitin Enzymology, vol. 2, pp. 21-36. Edited by R. A. A. Muzzarelli. Grottamara, Italy: Atec Edizioni.

Renkema, G. H., Boot, R. G., Muijsers, A. O., Donker-Koopman, W. E. \& Aerts, J. M. F. G. (1995). Purification and characterization of human chitotriosidase, a novel member of the chitinase family of proteins. J Biol Chem 270, 2198-2202.

Renkema, G. H., Boot, R. G., Strijland, A., Donker-Koopman, W. E., Van Den Berg, M., Muijsers, A. O. \& Aerts, J. M. F. G. (1997). Synthesis, sorting, and processing into distinct isoforms of human macrophage chitotriosidase. Eur J Biochem 244, 279-285.

Yagen, B., Bergmann, F., Barel, S. \& Sintov, A. (1991). Metabolism of T-2 toxin by rat brain homogenate. Biochem Pharmacol 42, 949-951.

Received 17 June 1998; revised 22 September 1998; accepted 5 October 1998. 